\title{
DIREITO AO ESQUECIMENTO E A TUTELA DOS DIREITOS FUNDAMENTAIS NA JURISPRUDÊNCIA DO TJ/SP ${ }^{1}$
}

RIGHT TO FORGETTING AND PROTECTING FUNDAMENTAL RIGHTS IN THE JURISPRUDENCE OF THE COURT OF JUSTICE OF THE STATE OF SÃO PAULO

Rafael Antônio RODRIGUES²

Ana Paula Bagaiolo MORAES ${ }^{3}$

ISSUE DOI: $10.21207 / 2675-0104.2018 .787$

\begin{abstract}
RESUMO
O avanço tecnológico, por meio do uso da internet, revela a facilidade com que informações são difundidas, além de limites territoriais e temporais. Nesse contexto, torna-se importante compreender que as alterações tecnológicas impõem alterações também no cenário jurídico. Assim, o presente estudo, a partir de análise jurisprudencial, apresenta o modo como o direito ao esquecimento tem se manifestado no Tribunal de Justiça do Estado de São Paulo e as divergências existentes quanto ao seu reconhecimento. Conforme análise de decisões proferidas por esse Tribunal, verificou-se que o direito ao esquecimento possui quatro maneiras distintas de se manifestar. Além disso, foi possível demonstrar que a técnica utilizada para a verificação sobre o reconhecimento deste direito revela-se insuficiente,
\end{abstract}

\footnotetext{
${ }^{1} \mathrm{O}$ presente artigo sintetiza a monografia de conclusão da pesquisa, realizada para o Programa Interno de Bolsas de Iniciação Científica (PIBIC 2017-2018) da Faculdade de Direito de Franca (FDF), Franca/SP.

${ }^{2}$ Discente da Faculdade de Direito de Franca (FDF), Franca/SP. Bolsista do Programa Interno de Bolsas de Iniciação Científica (PIBIC 2017-2018).

${ }^{3}$ Doutora em Direito Político e Econômico pela Universidade Presbiteriana Mackenzie (2018), Mestre em Direito Internacional pela Universidade Estadual Paulista Júlio de Mesquita Filho (2011), Especialista pela Fundação Armando Álvares Penteado em Direito do Agronegócio (2010) e Graduada pela Faculdade de Direito de Franca (2008). Atualmente é professora e atua nas áreas de Direito Civil (com ênfase em Parte Geral, Obrigações, Família e Sucessões) e Direito do Agronegócio, com projeto de pesquisa sobre os impactos do RenovaBio na região de Ituverava/SP pela Faculdade Dr. Francisco Maeda (FAFRAM).
} 
dada a insegurança jurídica existente. Desse modo, à medida que o tema tem se tornado recorrente, fazse imprescindível a formulação de critérios que garantam segurança jurídica.

Palavras-chave: Direito ao esquecimento. Privacidade. Liberdade de expressão. Princípio da ponderação.

\section{ABSTRACT}

The technological advance, through the use of the Internet, reveals the ease with which information is disseminated, as well as territorial and temporal limits. In this context, it is important to understand that technological changes also require changes in the legal environment. Thus, the present study, based on case law, presents how the right to forgetfulness has manifested itself in the Court of Justice of the State of São Paulo and the existing divergences regarding its recognition. According to the analysis of decisions handed down by this Court, it was found that the right to forget has four different ways of manifesting itself. Furthermore, it was possible to demonstrate that the technique used to verify the recognition of this right is insufficient, given the existing legal uncertainty. In this way, as the theme has become recurrent, it is essential to formulate criteria that guarantee legal certainty.

Keywords: Right to forgetfulness. Privacy. Freedom of expression. Principle of weighting.

\section{INTRODUÇÃO}

$\mathrm{O}$ art. $5^{\circ}$ da Constituição Federal elenca um vasto rol de direitos e garantias fundamentais, com vistas à concretização de uma sociedade livre, justa e solidária. No entanto, estes direitos, não raro, se conflitam quando se observa a amplitude de cada um deles. Soma-se a esse conflito a ausência de leis infraconstitucionais que regulem cada um destes direitos, como forma a delimitar os parâmetros de configuração.

É cediço que com o avanço dos meios digitais, principalmente a difusão do uso da internet, as notícias, consequentemente, são veiculadas de forma mais rápida e com maior amplitude. Ocorre que tais informações não são excluídas do contexto digital e podem ser rememoradas a qualquer momento.

Nesse contexto, o Poder Judiciário, por repetidas vezes tem sido provocado a se manifestar acerca da possibilidade de exclusão de certas notícias ou desindexação da relação dessas com o nome daquele que a pleiteia.

A esse pedido a doutrina tem empregado o nome de direito ao esquecimento, como sendo a intenção de determinado indivíduo de não ver acontecimentos de sua vida relembrados anos depois dos fatos que os ensejaram.

Para isso, o primeiro capítulo deste estudo destina-se, por meio de embasamento substancialmente bibliográfico, a indicar e diferenciar o direito à intimidade, à vida privada, à honra e à imagem, além do direito à liberdade de expressão, de informação e comunicação. Traça-se, também, 
os principais parâmetros empregados pela doutrina para balizar a liberdade de expressão.

O segundo capítulo destina-se a apresentar o conceito de direito ao esquecimento, bem como as principais implicações da sua efetivação no ordenamento jurídico brasileiro. Além disso, indica-se três casos tidos como referenciais para a efetivação deste direito no cenário jurídico internacional: os casos Melvin vs. Reid (Estados Unidos da América); Lebach (Alemanha) e Mario Costeja González (Espanha).

No terceiro capítulo explora-se, pelo aspecto de corrente jurisprudencial, o entendimento exarado pelo Tribunal de Justiça do Estado de São Paulo, acerca do direito ao esquecimento, a partir dos acórdãos proferidos.

A seleção dos julgados representativos do Tribunal mencionado ocorreu a partir da inserção do termo "direito e esquecimento" nos buscadores do sítio eletrônico do respectivo tribunal, limitada ao período entre 2013 e 2017.

A partir deste levantamento, foi criado um critério sistematizador, presente no anexo deste trabalho, com a finalidade de sistematizar as informações e analisar os reflexos do reconhecimento da teoria do esquecimento no TJ/SP.

Por fim, tem-se que o método adotado foi o da análise de decisões. Assim, como forma de cumprir os requisitos mínimos para a identificação metodológica, ressalta-se que os capítulos 1 e 2 dispuseram os conceitos básicos acerca da temática, fornecendo um substrato teórico, além da demonstração da relevância do assunto. Ainda, demonstra-se a análise crítica dos dados, aliando o interesse pelo tema com sua importância para o contexto prático atual.

\section{PRIVACIDADE E LIBERDADE DE EXPRESSÃO COMO DIREITOS CONSTITUCIONAIS EM CONFLITO}

\subsection{DIREITOS DA PERSONALIDADE E A DIGNIDADE HUMANA}

A Constituição Federal de 1988 estabeleceu em seu art. $5^{\circ}$, inciso $\mathrm{X}$, que "são invioláveis a intimidade, a vida privada, a honra e a imagem 
das pessoas, assegurando o direito a indenização pelo dano material ou moral decorrente de sua violação".

Nesse âmbito, a proteção da pessoa pela perspectiva do direito público recebe o nome de direitos fundamentais, enquanto que a expressão direitos da personalidade alude às ações humanas que necessitam de proteção no campo das relações privadas. Trata-se, como aduz Anderson Schreiber ${ }^{4}$, de um mesmo fenômeno, todavia "encarado por facetas variadas. O valor tutelado é idêntico e unitário: a dignidade humana".

Nas palavras de Orlando Gomes, os direitos da personalidade compreendem "direitos considerados essenciais ao desenvolvimento da pessoa humana, que a doutrina moderna preconiza e disciplina, no corpo do Código Civil, como direitos absolutos" $"$.

Os direitos da personalidade figuram como direitos heterogêneos e de fundamentação controvertida, razão pela qual Orlando Gomes traçou balizas ao seu objeto, relacionando-os a "bens jurídicos em que se convertem projeções físicas ou psíquicas da pessoa humana por determinação legal, que os individualiza para lhes dispensar proteção" 6 .

E, no que tange à unificação dos direitos da personalidade, a tese é refutada pelo autor citado, o qual entende que a teoria dos direitos da personalidade deve se apoiar no direito positivo e reconhecer o pluralismo desses direitos frente à pluralidade de bens jurídicos sobre que recaem ${ }^{7}$.

Nota-se que a previsão de tais direitos em um mesmo dispositivo suscita dúvida referente às diferenças existentes entre tais termos. Convém, dessa forma, elencar, ainda que sucintamente, o conceito e as principais diferenças entre o conteúdo de cada um dos direitos tutelados.

\section{$2.2 \quad$ DIREITOS DE PRIVACIDADE}

O direito à intimidade corresponde à "discrição pessoal atinente aos acontecimentos e desenvolvimento da vida do sujeito, dentre outros,

\footnotetext{
${ }^{4}$ SCHREIBER, Anderson. Direitos da personalidade. 2. ed. São Paulo: Atlas, 2013. p. 13.

${ }^{5}$ GOMES, Orlando. Introdução ao Direito Civil. 5. ed. Rio de Janeiro: Forense, 1977. p. 168.

${ }^{6}$ GOMES, op. cit., p. 171.

${ }^{7}$ GOMES, op. cit., p. 172.
} 
aos seguintes aspectos: confidenciais, informes de ordem pessoal (dados pessoais), lembranças de família, sepultura, vida amorosa" ${ }^{\text {. }}$.

Por sua vez, o direito à vida privada refere-se a questão de liberalidade por parte de seu titular do modo como optou por viver, todavia, deve-se levar em consideração o comportamento da pessoa, bem como o nível de sua inserção no contexto da vida social ${ }^{9}$.

A privacidade propriamente dita ou vida privada relaciona-se à "noção das relações interindividuais que, como as nucleadas na família, devem permanecer ocultas ao público"10.

Luiz Alberto David Araujo e Vidal Serrano Nunes Júnior afirmam que a vida social ultrapassa a perspectiva de público e privado, já que existe uma nova subdivisão entre a intimidade e privacidade propriamente dita ${ }^{11}$.

Assim, os dois direitos foram incluídos em um único tópico, no entanto, como já exposto, tratam de conteúdos distintos, sendo que ambos podem ser incluídos em um conceito mais amplo, o de direito de privacidade.

$\mathrm{O}$ direito à privacidade apresenta como marco inicial o artigo The Right to Privacy, publicado no ano de 1890, na Harvard Law Review. O artigo, motivado pelo destaque exagerado dado pelos jornais de Boston à mulher de um dos autores, apresentou de forma individualista o direito à privacidade como um direito a ser deixado só ${ }^{12}$.

Não se pode olvidar que a notoriedade do direito à privacidade deve-se, em grande parte, pelo desenvolvimento tecnológico e consequente aumento na facilidade de se recolher, armazenar e difundir informações, por isso na esteira da privacidade deve-se incluir o direito da pessoa de manter o controle sobre os seus dados pessoais.

O estudo em tela enfoca substancialmente a privacidade sob esse aspecto do controle acerca dos dados pessoais, tendo em vista o avanço tecnológico marcado pela difusão célere e irrestrita de notícias e informações privadas.

\footnotetext{
${ }^{8}$ FARIAS, Edilsom Pereira de. Colisão de direitos: A honra, a intimidade, a vida privada e a imagem versus a liberdade de expressão e informação. Porto Alegre: Sergio Antonio Fabris Editor, 1996. p. 114.

${ }^{9}$ FARIAS, op. cit., p. 119.

${ }^{10}$ ARAUJO, Luiz Alberto David; NUNES JÚNIOR, Vidal Serrano. Curso de Direito Constitucional. 14. ed. São Paulo: Saraiva, 2010. p. 174.

${ }^{11}$ ARAUJO; NUNES JÚNIOR, op. cit., p. 174.

${ }^{12}$ SCHREIBER, Anderson. Direitos da personalidade. 2. ed. São Paulo: Atlas, 2013. p. 134-135.
} 


\subsection{DIREITO À HONRA}

José Afonso da Silva conceitua honra como "o conjunto de qualidades que caracterizam a dignidade da pessoa, o respeito dos concidadãos, o bom nome, a reputação"13.

Por sua vez, Edilsom Pereira de Farias apresenta duas características quanto ao direito à honra: a primeira diz respeito à sua relação com a dignidade da pessoa humana, tendo em vista que "a honra é atributo inerente a qualquer pessoa independentemente de considerações de raça, religião, classe social"; a segunda característica refere-se ao conteúdo objetivo e subjetivo da honra. No sentido objetivo traduz "a reputação que a pessoa desfruta ante o meio social em que está situada", enquanto que no aspecto subjetivo "é a estimação que a pessoa realiza de sua própria dignidade moral"14.

Assim, depreende-se que a honra, compreendida em seus aspectos internos e externos, goza de proteção que ultrapassa a esfera infraconstitucional, tendo em vista que o art. $5^{\circ}$, inciso $\mathrm{X}$, do Texto Constitucional tutela a sua inviolabilidade.

\subsection{DIREITO À IMAGEM}

O direito à imagem pode ser conceituado de um lado "como o direito relativo à reprodução gráfica (retrato, desenho, fotografia, filmagem etc.) da figura humana. De outro lado, "a imagem assume a característica do conjunto de atributos cultivados pelo indivíduo e reconhecidos pelo conjunto social" 15 .

Uadi Lammêgo Bulos vislumbra três tipos de imagem no Texto Constitucional. O primeiro, a imagem social, prevista no art. $5^{\circ}$ inciso $\mathrm{V}$, expressa "os atributos exteriores da pessoa física ou jurídica, com base naquilo que ela própria transmite na vida em sociedade". O segundo, a imagem-retrato, "é a imagem física do indivíduo, [...] fisionomia, partes do corpo, gestos, expressões, atitudes, traços fisionômicos, sorrisos" captados

\footnotetext{
${ }^{13}$ SILVA, José Afonso da. Curso de Direito Constitucional Positivo. 36. ed. São Paulo: Malheiros, 2013. p. 211.

${ }^{14}$ FARIAS, Edilsom Pereira de. Colisão de direitos: A honra, a intimidade, a vida privada e a imagem versus a liberdade de expressão e informação. Porto Alegre: Sergio Antonio Fabris Editor, 1996. p. 109.

${ }^{15}$ ARAUJO, Luiz Alberto David; NUNES JÚNIOR, Vidal Serrano. Curso de Direito Constitucional. 14. ed. São Paulo: Saraiva, 2010. p. 177.
} 
a partir de recursos tecnológicos e artificiais. $\mathrm{O}$ terceiro, a imagem autoral, diz respeito à imagem do autor que participa em obras coletivas, tendo como requisito a participação ativa ${ }^{16}$.

Por fim, insta salientar que o direito à própria imagem se distingue do direito à intimidade, tendo em vista que o primeiro pode ser infringido sem que se fira a intimidade, como é o caso da veiculação de uma imagem antiga. Também, não se confunde com o direito à honra, pois a veiculação de uma imagem sem autorização de seu titular pode ferir o direito à própria imagem, mas não o direito à honra ${ }^{17}$.

Desse modo, pode-se dizer que enquanto a honra tutela o reconhecimento interior e exterior dos próprios valores, a imagem garante a proteção dos elementos externos inerentes a determinada pessoa, na perspectiva da valoração por parte da coletividade.

\subsection{LIBERDADES DE EXPRESSÃO E INFORMAÇÃO}

Convém apresentar as diferenças entre tais direitos. A liberdade de informação refere-se ao direito pessoal de comunicar livremente acontecimentos, bem como ao direito de ser deles informado. A liberdade de expressão tutela o direito à exteriorização de ideias, opiniões, juízos de valor $^{18}$.

Há que se falar ainda em uma terceira interpretação, qual seja, a liberdade de comunicação, anteriormente conhecida como liberdade de imprensa. Esta liberdade "consiste num conjunto de direitos, formas, processos e veículos, que possibilitam a coordenação desembaraçada da criação, expressão e difusão do pensamento e da informação"19.

$\mathrm{O}$ direito de informação jornalística, inserido no contexto da liberdade de comunicação, constitui uma "garantia institucional da democracia”, o que justifica ser um direito preferencial em relação aos

\footnotetext{
${ }^{16}$ BULOS, Uadi Lammêgo. Curso de Direito Constitucional. 8. ed. São Paulo: Saraiva, 2014. p. 572573.

${ }^{17}$ FARIAS, Edilsom Pereira de. Colisão de direitos: A honra, a intimidade, a vida privada e a imagem versus a liberdade de expressão e informação. Porto Alegre: Sergio Antonio Fabris Editor, 1996. p. 157.

${ }^{18}$ BARROSO, Luis Roberto. Colisão entre liberdade de expressão e direitos da personalidade. Critérios de ponderação. Interpretação constitucionalmente adequada do código civil e da lei de imprensa. Revista de Direito Administrativo, Rio de Janeiro, v. 235, p.1-36, mar. 2004. p. 18.

${ }^{19}$ SILVA, José Afonso da. Curso de Direito Constitucional Positivo. 36. ed. São Paulo: Malheiros, 2013. p. 245.
} 
demais. A ideia de ser preferencial, porém, não o coloca como um direito ilimitado, pois deve existir "diante de fatos cujo conhecimento seja importante para que o indivíduo possa participar do mundo em que vive" 20 .

André Ramos Tavares interpreta a liberdade de expressão a partir de duas dimensões: substantiva e instrumental. A substantiva exterioriza a importância da liberdade pois veicula seu conteúdo, o qual "diz respeito à autodeterminação do indivíduo, sensivelmente conectada com a dignidade da pessoa humana". A dimensão instrumental, por sua vez, refere-se à "possibilidade de eleger o meio mais adequado para veicular, transmitir as opiniões e ideias emitidas pelo indivíduo, com a finalidade de que se atinja um certo número de receptores o que, aliás, está ínsito à própria ideia de

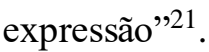

A partir dessa segunda dimensão é que se pode falar em liberdades de comunicação, radiodifusão, dentre outras, desde que relacionadas à veiculação de informações, razão pela qual foram incluídas em um único tópico.

Dessa maneira, a liberdade de informar insere no contexto jurídico a perplexidade sobre o que pode e deve ser veiculado como notícia, já que este último termo, usualmente, remete a fatos tornados públicos. Ademais, suscita o questionamento acerca da expiração ou não do prazo a que está submetida a veiculação destas informações.

\subsubsection{LIMITES À LIBERDADE DE EXPRESSÃO}

A Constituição, em seu texto, prevê critérios para o exercício da liberdade de expressão. Em primeiro lugar, a vedação da censura não pode legitimar a prática de atos ilícitos, tal como elencado por Uadi Lammêgo Bulos $^{22}$. Em segundo lugar, tem-se a previsão do art. 220, parágrafo $3^{\circ}$, que tutela a necessidade de informação do conteúdo ventilado em sua programação, por parte do Poder Público.

Deve-se levar em consideração, também, que a liberdade de expressão como direito preferencial, do qual provém as bases da

\footnotetext{
${ }^{20}$ ARAUJO, Luiz Alberto David; NUNES JÚNIOR, Vidal Serrano. Curso de Direito Constitucional. 14. ed. São Paulo: Saraiva, 2010. p. 168-169.

${ }^{21}$ TAVARES, André Ramos. Liberdade de expressão-comunicação, limitações quanto ao seu exercício e possibilidade de regulamentação. In: CAMARGO, Marcelo Novelino (Org.). Leituras complementares de direito constitucional: Direitos Fundamentais. 2. ed. Salvador: Juspodivm, 2007. p. 234-235.

${ }^{22}$ BULOS, Uadi Lammêgo. Curso de Direito Constitucional. 8. ed. São Paulo: Saraiva, 2014. p. 580.
} 
democracia, não pode prejudicar ninguém, em nenhum de seus direitos, por uma questão de coerência.

Constituem, ainda, como balizadores externos ao exercício da liberdade de expressão o direito à honra, à intimidade, à vida privada e à imagem, todavia, como são também direitos alçados ao status de direitos fundamentais, quando conflitam com a liberdade de expressão, há colisão entre direitos fundamentais, "cuja solução do confronto, se revela um dos problemas nucleares a desafiar a hodierna dogmática sobre os direitos fundamentais",23.

Por esta via, partindo-se da concepção de que os princípios devem orientar a efetivação da liberdade de expressão, não se deve descuidar da necessidade de análise do caso concreto.

\subsection{DIREITOS FUNDAMENTAIS EM CONFLITO}

O contexto atual, marcado pelo avanço massivo da tecnologia, impõem alterações também no contexto jurídico. A facilidade com que informações são armazenadas e veiculadas, bem como a quantidade e a qualidade delas são elementos que conflitam com a exposição pessoal e a tutela dos direitos da personalidade.

O tema assume uma grandeza maior quando se verifica a existência de controvérsia entre dois direitos fundamentais, caso em que, parte da doutrina tem se posicionado pela necessidade de ponderação entre o conteúdo de cada um dos direitos.

Os direitos fundamentais possuem caráter dúplice: como direitos de defesa ou direitos negativos e direitos a prestações fáticas e jurídicas ou direitos positivos, correspondem a concretização da dignidade humana, mas também à necessidade de respeito (não-violação) e proteção, como forma de se garantir um mínimo existencial ${ }^{24}$.

Atenta-se ao fato de que estes direitos constituem direitos heterogêneos e de conteúdo aberto e variável, o que se acrescenta à situação de choque entre direitos fundamentais ${ }^{25}$.

\footnotetext{
${ }^{23}$ FARIAS, Edilsom Pereira de. Colisão de direitos: A honra, a intimidade, a vida privada e a imagem versus a liberdade de expressão e informação. Porto Alegre: Sergio Antonio Fabris Editor, 1996. p. 137.

${ }^{24}$ SARLET, Ingo Wolfgang. Dignidade da pessoa humana e direitos fundamentais na Constituição de 1988. 4. ed. Porto Alegre: Livraria do Advogado, 2006. p. 98.

${ }^{25}$ FARIAS, Edilsom Pereira de. Colisão de direitos: A honra, a intimidade, a vida privada e a imagem versus a liberdade de expressão e informação. Porto Alegre: Sergio Antonio Fabris Editor, 1996. p. 93.
} 
Assim, a solução da controvérsia entre direitos fundamentais deve atuar com o fim de restringi-los minimamente, e na preferência por um direito, "não se deve aniquilar totalmente o outro, mas preservar-lhe um mínimo irredutível chamado núcleo essencial" 26 .

Nas palavras de José Joaquim Gomes Canotilho, a tensão entre direitos fundamentais não pode obedecer uma "lógica do tudo ou nada", mas deve pautar-se na ponderação e concordância prática, levando-se em consideração o peso atribuído a tal princípio ou norma e os aspectos que permeiam o caso concreto ${ }^{27}$.

Dessa forma, revela-se imprescindível a análise fática, pois será esta a responsável por indicar o peso a ser atribuído a cada um dos princípios em conflito.

\subsubsection{A TÉCNICA DA PONDERAÇÃO E A CRÍTICA AO SEU USO}

A técnica da ponderação é apresenta por Luis Roberto Barroso a partir de três critérios, os quais constituem o caminho para a identificação e equilíbrio entre os direitos conflitantes.

Na primeira etapa compete ao intérprete agrupar as normas que se relacionam com o caso, não se podendo descuidar do fato de que norma não se confunde com dispositivo, ou seja, pode haver dispositivo sem norma e dispositivo com mais de uma norma. Esta etapa visa formar possíveis conjuntos argumentativos, que se resumem na solução semelhante dada pelas normas ${ }^{28}$.

A segunda etapa constitui-se pela análise dos fatos e as relações existentes com as normas, momento no qual serão preenchidas de real sentido, assim, "o exame dos fatos e os reflexos sobre eles das normas

\footnotetext{
${ }^{26}$ FARIAS, op. cit., p. 19.

${ }^{27} \mathrm{O}$ autor supra ilustra a perspectiva da ponderação do seguinte modo: se o princípio democrático obtém concretização através do princípio maioritário, isso não significa desprezo da protecção das minorias (cfr., por ex., art. 117. ${ }^{\circ}$ sobre o estatuto de oposição); se o princípio democrático, na sua dimensão económica, exige intervenção conformadora do Estado através de expropriações e nacionalizações, isso não significa que se posterguem os requisitos de segurança inerentes ao princípio do Estado de direito (princípio de legalidade, princípio de justa indemnização, princípio de acesso aos tribunais para discutir a medida de intervenção) (CANOTILHO, José Joaquim Gomes. Direito Constitucional. 6. ed. Coimbra: Almedina, 1993. p. 190).

28 BARROSO, Luis Roberto. Curso de Direito Constitucional contemporâneo: Os conceitos fundamentais e a construção do novo modelo. São Paulo: Saraiva, 2009. p. 334.
} 
identificadas na primeira fase poderão apontar com maior clareza o papel de cada uma delas e a extensão de sua influência"29.

A última etapa dá-se com a aplicação de limites a cada um dos direitos em conflito, bem como pela análise dos conjuntos argumentativos em que ocorrerá a atribuição de pesos a cada grupo de normas, devendo pautar-se no princípio da razoabilidade.

Nesta esteira, Anderson Schreiber apresenta parâmetros concernentes ao grau de realização do exercício da liberdade de informação em detrimento da veiculação de imagens:

(i) o grau de utilidade para o público do fato informado por meio da imagem; (ii) o grau de atualidade da imagem; (iii) o grau de necessidade da veiculação da imagem para informar o fato; $\mathrm{e}$ (iv) $\mathrm{o}$ grau de preservação do contexto originário onde a imagem foi colhida. Para aferir a intensidade do sacrifício imposto ao direito de imagem, cumpre verificar: (i) o grau de consciência do retratado em relação à possibilidade de captação da sua imagem no contexto de onde foi extraída; (ii) o grau de identificação do retratado na imagem veiculada; (iii) a amplitude da exposição do retratado; e (iv) a natureza e o grau de repercussão do meio pelo qual se dá a divulgação da imagem ${ }^{30}$.

Lênio Luiz Streck posiciona-se contrário ao emprego de ponderação entre os princípios, por se configurar um meio "pelo qual o mesmo princípio é utilizado para sustentação de teses antitéticas" 31 .

Nesse âmbito, a partir do sopesamento ou ponderação é possível que o julgador chegue a respostas diversas, "ou seja, casos idênticos acabam recebendo decisões diferentes, tudo sob o manto da 'ponderação' e suas decorrências" 32 .

A fragilidade da aplicação direta da ponderação é evidenciada por Daniel Peixoto Murata a partir de seu emprego em um caso hipotético. A análise do caso demonstra a insuficiência da aplicação da técnica para sanar o conflito presente entre a segurança pública ${ }^{33}$.

Da exposição feita, é possível perceber que não existem critérios fixos para a satisfação entre os direitos em conflito. Assim, constitui

\footnotetext{
${ }^{29}$ BARROSO, op. cit., p. 335.

${ }^{30}$ SCHREIBER, op. cit., p. 114.

${ }^{31}$ STRECK, Lenio Luiz. O que é isto - decido conforme minha consciência? 4. ed. Porto Alegre: Livraria do Advogado, 2013. p. 51.

${ }^{32}$ STRECK, op. cit., p. 52.

${ }^{33}$ Vide: MURATA, Daniel Peixoto. Proporcionalidade - insuficiências morais e teóricas. Teoria Jurídica Contemporânea, Rio de Janeiro, v. 2, n. 1, p.36-62, dez. 2016. p. 47-48).
} 
desafio de grande monta aos Tribunais realizar tal tarefa, todavia, no que tange ao tema do direito ao esquecimento, não se pode descuidar da observância do interesse público, bem como da legalidade dos conteúdos em discussão, pois se a restrição na veiculação de informações por meio de seus mecanismos reprodutores pode ensejar censura, a falta de limites ao direito de informar também pode caracterizar violação ao direito fundamental à intimidade.

\section{DIREITO AO ESQUECIMENTO}

\subsection{CONCEITO E NATUREZA JURÍDICA DO DIREITO AO ESQUECIMENTO}

$\mathrm{O}$ avanço tecnológico ensejou alterações no campo jurídico, tendo em vista que as relações sociais, em decorrência disso, também passaram por transformações. As leis que previam implicações e divergências apenas no contexto interpessoal e material necessitaram de alterações para incluir as implicações do cenário digital.

Neste contexto, a Lei $n^{\circ} 12.965$, de 23 de abril de 2014 estabeleceu os princípios, garantias, direitos e deveres para o uso da Internet no Brasil. Em seu art. $7^{\circ}$, inciso X, a Lei cuida da possibilidade de exclusão dos dados pessoais fornecidos a determinada aplicação da internet, ao término da relação entre as partes. Há quem entenda que o teor deste inciso trouxe para o ordenamento jurídico brasileiro a previsão legal acerca do direito ao esquecimento ${ }^{34}$.

O direito ao esquecimento, nas palavras de Cintia Rosa Pereira de Lima, constitui:

${ }^{34}$ LIMA, Cíntia Rosa Pereira de. Direito ao esquecimento e internet: o fundamento legal no direito comunitário europeu, no direito italiano e no direito brasileiro. Revista dos Tribunais Online, São Paulo, v. 8, p.511-543, ago. 2015. p. 18. 
de liberdade de expressão, científica, artística, literária e jornalística ${ }^{35}$.

Por sua vez, João Martins Neto e Denise Pinheiro apresentam o direito ao esquecimento como

O direito de não ser citado no corpo de um relato atual sobre eventos pretéritos de caráter público; é o direito de não ser lembrado, de não ter uma passagem ruim da vida - outrora legitimamente tornada pública por sua conexão com fatos terríveis - recontada agora, tantos anos depois, apesar da sua veracidade e desde que a evocação da história se mostre nociva à vida da pessoa implicada ${ }^{36}$.

Diz-se que a tutela do esquecimento encontra sua origem nos direitos à intimidade e à proteção dos dados pessoais ${ }^{37}$.

Tal afirmação não se revela pacifica. João Martins Neto e Denise Pinheiro entendem que o direito ao esquecimento não se confunde com o direito à privacidade, pois diz respeito a fato pretérito passível de ser transformado em notícia pelo seu interesse público e que pelo decurso do tempo não deve mais ser tornado público. ${ }^{38}$.

Por conseguinte, no âmbito doutrinário, destaca-se o questionamento acerca da autonomia deste direito. Trata-se de um aspecto divergente, mas necessário para a identificação do seu objeto e seus fundamentos.

Regina Ruaro e Fernando Machado atribuem o direito ao esquecimento como um desdobramento dos direitos à privacidade e a proteção de dados pessoais, porquanto os parâmetros de ponderação entre tais direitos se confundem, "inexistindo inovação sequer em relação ao fator temporal" 39 .

Cintia Rosa Pereira de Lima identifica o direito ao esquecimento como sendo um direito de personalidade autônomo, tendo em vista a

\footnotetext{
${ }^{35}$ LIMA, op. cit., p. 12.

${ }^{36}$ MARTINS NETO, João dos Passos; PINHEIRO, Denise. Liberdade de informar e direito à memória - uma crítica à ideia do direito ao esquecimento. Revista Novos Estudos Jurídicos, Itajaí, v. 19, n. 3, p.808-838, dez. 2014. p. 811.

${ }^{37}$ QUESADA, Francisco Mesa. Dimensión constitucional del derecho al olvido. Derecho y Cambio Social, Lima, v. 49, p.1-31, set. 2017. p. 8.

${ }^{38}$ MARTINS NETO, João dos Passos; PINHEIRO, Denise. Liberdade de informar e direito à memória - uma crítica à ideia do direito ao esquecimento. Revista Novos Estudos Jurídicos, Itajaí, v. 19, n. 3, p.808-838, dez. 2014. p. 811. p. 811.

${ }^{39}$ RUARO, Regina Linden; MACHADO, Fernando Inglez de Souza. Ensaio a propósito do direito ao esquecimento: limites, origem e pertinência no ordenamento jurídico brasileiro. Revista de Direito Público, Londrina, v. 17, n. 1, p.204-233, maio 2017. p. 230.
} 
existência de um fator chamado "contexto temporal" 40 . Por este fator, o indivíduo requer que alguns fatos de sua vida sejam esquecidos, os quais ficaram no passado.

A justificativa do fator tempo decorre do conteúdo do art. $6^{\circ}$ da Diretiva 2002/58/CE, que estipula prazo para a manutenção dos tráfegos de dados. Este lapso temporal "pode constituir uma nova situação jurídica, isto é, um direito subjetivo do interessado em eliminar a informação por ter transcorrido um prazo prolongado e a informação perdeu sua utilidade" 41 .

Assim, o presente estudo não incluiu em seu rol de objetivos o estabelecimento de um conceito único para o direito ao esquecimento, nem a definição dos elementos que o constitui, dado que se trata de tema recente e ainda em exploração pelos segmentos doutrinários.

\subsection{PRINCIPAIS BASES HISTÓRICAS}

O direito ao esquecimento tem sua base histórica no contexto das condenações criminais, sob a perspectiva de que os condenados que já cumpriram pena possuem o direito à ressocialização e o de não serem constantemente perseguidos pelos atos praticados anteriormente ${ }^{42}$.

Trata-se de tema que permite diversas interpretações e reflexos, como se poderá perceber ao longo deste trabalho, razão pela qual faz-se pertinente a apresentação sucinta de três dos principais casos que evidenciaram a possibilidade de existência do direito ao esquecimento.

O primeiro caso diz respeito ao julgamento proferido pela Court of Appeal of California, tendo como recorrente Gabrielle Darley, a qual pretendia reparação por conta de um filme, intitulado The Red Kimono, em que fora retratada como prostituta e acusada de um assassinato. A recorrente, posteriormente, casou-se com Bernard Melvin, em 1919, deixando a prostituição e tendo comprovada a inocência da acusação que lhe era imputada através do julgamento ${ }^{43}$.

Manifestou o Tribunal, reconhecendo a pretensão de Gabrielle, que o uso do seu nome verdadeiro veiculado em relação aos fatos de sua

\footnotetext{
${ }^{40}$ LIMA, Cíntia Rosa Pereira de. Direito ao esquecimento e internet: o fundamento legal no direito comunitário europeu, no direito italiano e no direito brasileiro. Revista dos Tribunais Online, São Paulo, v. 8, p.511-543, ago. 2015. p. 11.

${ }^{41}$ LIMA, op. cit., p. 11.

${ }^{42}$ SCHREIBER, Anderson. Direitos da personalidade. 2. ed. São Paulo: Atlas, 2013. p. 170.

${ }^{43}$ COURT OF APPEAL OF CALIFORNIA. MELVIN v. REID: documento eletrônico. California: 1931. Disponível em: <https://casetext.com/case/melvin-v-reid>. Acesso em 05 ago. 2018.
} 
vida indicou uma atitude desnecessária e que o direito a uma vida livre não pode permitir ataques injustificados à liberdade, propriedade e reputação. Ademais, salientou que um dos principais objetivos da sociedade e do sistema penal é a reabilitação dos indivíduos e, ainda mais quando essa reabilitação ocorre de forma autônoma, deve-se permitir a continuidade de tal postura sem expô-la novamente ${ }^{44}$.

O segundo caso refere-se ao conflito no qual a emissora de televisão ZDF (Zweites Deutsches Fernsehen) planejava a exibição de um documentário sobre o assassinato de soldados de Lebach, na Alemanha. Um dos condenados entendeu que a exibição do documentário prejudicaria seu direito à ressocialização, já que a época da exibição coincidiria com a sua libertação ${ }^{45}$.

O Tribunal Constitucional Federal reconheceu a existência de conflito entre a proteção da personalidade e a liberdade de informar, bem como a precedência do direito de informar quando tiver por objeto matéria sobre ocorrência de crime. Posteriormente, constatou que a matéria não se encontrava revestida por um interesse atual pela informação, e que poderia ameaçar a ressocialização do autor ${ }^{46}$.

O terceiro caso trata de decisão do Tribunal de Justiça da União Europeia, referente ao Processo C-131/12, em que o Tribunal foi provocado a se manifestar sobre a proteção e circulação dos dados pessoais.

O pedido decorreu de embate entre a empresa Google Spain SL e Google Inc. e a Agência Espanhola de Proteção de Dados - AEPD e Mario Costeja González, no qual a AEPD deferiu a reclamação apresentada pelo autor determinando que a empresa Google retirasse dos seus índices de pesquisa os dados pessoais do autor, afim de impossibilitar o acesso futuro.

A reclamação apresentada por Mario Costeja González dizia respeito a publicação de matéria em um jornal de considerável repercussão, da Catalunha. Quando o nome do requerente era inserido em mecanismos de buscas, obtinha-se ligação com duas páginas do jornal La Vanguardia, datadas de 19 de janeiro e 9 de março de 1998, onde existia um anúncio de venda de imóveis decorrente de dívidas com a Segurança Social ${ }^{47}$.

\footnotetext{
${ }^{44}$ COURT OF APPEAL OF CALIFORNIA, op. cit.

${ }^{45}$ ALEXY, Robert. Teoria dos Direitos Fundamentais. 2. ed. São Paulo: Malheiros, 2015. p. 100.

${ }^{46}$ ALEXY, op. cit., p. 165.

47 TRIBUNAL DE JUSTIÇA. Acórdão - Processo C 131/12: documento eletrônico. Luxemburgo: $2014 . \quad$ Disponível em: <https://eur-lex.europa.eu/legalcontent/EN/ALL/?uri=CELEX\%3A62012CJ0131>. Acesso em: 05 ago. 2018.
} 
O pedido do autor foi o de supressão ou alteração da matéria relacionada a ele das páginas do La Vanguardia Ediciones SL, além da pretensão contra a empresa Google, para a supressão ou ocultação dos seus dados pessoais do mecanismo de busca ${ }^{48}$.

Após recurso da empresa Google, a questão foi remetida ao Tribunal de Justiça, onde houve a responsabilização do operador do motor de busca pela perspectiva de que permitem "uma visão global mais estruturada das informações sobre essa pessoa, que se podem encontrar na Internet, que lhes permita estabelecer um perfil mais ou menos detalhado da pessoa em causa" ${ }^{, 49}$.

Desse modo, o Tribunal de Justiça, por meio da Grande Seção, interpretou os artigos $2^{\circ}, 4^{\circ}$ e $12^{\circ}$ da Diretiva 95/46/CE do Parlamento Europeu e do Conselho, de 24 de outubro de 1995. No que tange ao art. $2^{\circ}$, a interpretação foi no sentido de que a atividade dos motores de buscas de encontrar informações, indexá-las, armazená-las temporariamente e oferecê-las ao público segundo uma ordem de preferência deve ser reconhecida como "tratamento de dados pessoais", pelo qual devem ser responsabilizados ${ }^{50}$.

O caso espanhol ensejou críticas à defasagem de regulamentação do tema acerca da proteção de dados pessoais, que é feita com base na Diretiva 95/46/CE. Assim, em 2016 foi aprovada um novo regulamento, 2016/679, cuja aplicação se dará a partir de maio de 2018. O principal objetivo deste regulamento é a proteção das pessoas quanto ao tratamento de dados de caráter pessoal, bem como a maneira e amplitude da circulação.

\subsection{IMPLICAÇÕES JURÍDICAS DO DIREITO AO ESQUECIMENTO}

O direito de ser esquecido dos meios de comunicação, segundo Schreiber "não atribui a ninguém o direito de apagar fatos ou de reescrever a História (ainda que se trate tão somente da sua história) "'51. Dá-se apenas a possibilidade de discussão no que tange ao uso dos fatos pretéritos.

\footnotetext{
${ }^{48}$ TRIBUNAL DE JUSTIÇA, op. cit.

${ }^{49}$ TRIBUNAL DE JUSTIÇA, op. cit.

${ }^{50}$ TRIBUNAL DE JUSTIÇA, op. cit. Item 100.1.

${ }^{51}$ SCHREIBER, Anderson. Direitos da personalidade. 2. ed. São Paulo: Atlas, 2013. p. 171.
} 
Por conseguinte, o reconhecimento do direito ao esquecimento envolve-se, como já exposto no capítulo anterior, com a liberdade de expressão e informação por suas diversas manifestações, inclusive no âmbito digital.

$\mathrm{O}$ acesso à internet deve ser entendido como um dos direitos comunicativos próprio da pós-modernidade e "à medida que a Internet representa uma ferramenta da liberdade de expressão e do exercício da cidadania, tem-se que o seu acesso há de ser completamente livre a todos os cidadãos (independente de permissão ou autorização do Estado) " ${ }^{52}$.

Não obstante tratar-se de um direito comunicativo, e que deve ser utilizado de forma livre, tal liberdade não deve abranger um uso irresponsável e desprovido de licitude. Assim, entende-se que há limites, seja para o uso da comunicação, seja para a efetivação do direito ao esquecimento.

Assim, Cintia Pereira de Lima elenca os possíveis requisitos para a concretização deste direito: i) decurso do tempo em relação à ocorrência do fato; ii) ausência de utilidade pública ou social; iii) não alteração da verdade dos fatos; iv) não aplicação às instituições comunicativas afeitas a aspectos jornalísticos, literários ou científicos ${ }^{53}$.

Francisco Mesa Quesada elucida a necessidade de limitação ao direito ao esquecimento:

\begin{abstract}
Al final, no se trata de un derecho a la autodeterminación informativa o a la construcción de un perfil digital propio, a gusto de la persona afectada por la información que se publique sobre ella em Internet. Por otro lado, estamos hablando de casos en los que los datos a los que se vincula el enlace informático que aparezca en la lista de enlaces web del motor sean inapropiados, o excesivos desde la perspectiva de la finalidad para los que fueron tratados, según establece la jurisprudência comunitaria ${ }^{54}$.
\end{abstract}

Os parâmetros traçados indicam que o direito ao esquecimento não pode ser aplicado a instituições jornalísticas. Desse modo, o caso Mario Costeja González indica a limitação à proteção do dado pessoal do indivíduo. No entanto, deve-se atentar para o fato de que no Brasil, embora

\footnotetext{
${ }^{52}$ MAZZUOLI, Valerio de Oliveira. Direitos comunicativos como direitos humanos: abrangência, limites, acesso à Internet e direito ao esquecimento. Revista do Direito de Língua Portuguesa, Lisboa, v. 6, n. 1, p.219-240, dez. 2015. p. 237-238.

${ }^{53}$ LIMA, Cíntia Rosa Pereira de. Direito ao esquecimento e internet: o fundamento legal no direito comunitário europeu, no direito italiano e no direito brasileiro. Revista dos Tribunais Online, São Paulo, v. 8, p.511-543, ago. 2015. p. 18.

${ }^{54}$ QUESADA, Francisco Mesa. Dimensión constitucional del derecho al olvido. Derecho y Cambio Social, Lima, v. 49, p.1-31, set. 2017. p. 12.
} 
exista significativa divergência jurisprudencial, há casos de interferência no contexto próprio do jornalismo, como se verá no capítulo 3.

\section{O DIREITO AO ESQUECIMENTO NA PERSPECTIVA DAS DECISÕES PROFERIDAS PELO TJ/SP}

\subsection{ESTUDO DE CAMPO: ANÁLISE JURISPRUDENCIAL COMPARATIVA}

O objeto deste terceiro capítulo refere-se à exposição de acórdãos proferidos pelo Tribunal de Justiça do Estado de São Paulo. A delimitação em relação ao TJ/SP se deu pois, embora a análise não se baseie apenas em um aspecto quantitativo, o tribunal mencionado foi responsável pelo maior número de julgados acerca do tema. Além disso, se comparado ao TJ/RJ, foi o tribunal que mais julgou casos relacionados ao uso da internet.

Ressalta-se que o tema, embora tenha tido reconhecimento de repercussão geral em sede recursal no STF, ainda não foi julgado, razão esta que justifica a ausência da análise de decisões desta Corte.

A partir do acesso ao sítio eletrônico do Tribunal de Justiça do Estado de São Paulo, ocorrido entre os meses de novembro de 2017 e janeiro de 2018, no espaço reservado a "jurisprudência", no campo "pesquisa livre", foram introduzidas conjuntamente as seguintes palavras "direito" e "esquecimento", cuja pesquisa resultou na obtenção de 8.038 decisões, o que inviabilizaria a análise. Dessa forma, os mesmos termos foram introduzidos no campo "ementa", sendo que 125 decisões foram encontradas, o que revela, de forma plausível, a possibilidade de análise. Das 120 decisões, apurou-se que apenas 41 relacionavam-se com o objetivo pretendido, sendo que nas demais o termo "esquecimento" foi empregado com outro sentido. As 41 decisões foram extraídas do sítio eletrônico por meio da opção "inteiro teor" e observadas sob a perspectiva do critério sistematizador desenvolvido. Na fase de observação, a partir do critério sistematizador, excluiu-se mais 1 decisão, pois tinha por objeto discussão sobre condenação criminal ${ }^{55}$.

\footnotetext{
${ }^{55}$ As decisões acerca do direito ao esquecimento, no que tange à matéria criminal, não foram incluídas neste estudo pois relacionam-se a tema já pacificado no âmbito do Superior Tribunal de Justiça, no
} 
O critério sistematizador possui quatro pontos distintos: o primeiro, com exigências do tipo de recurso, origem, relator, data de recebimento e julgamento, refere-se às informações técnicas concernentes ao acórdão; o segundo ponto diz respeito à identificação do pedido, pois como será possível perceber, a pretensão pode relacionar o direito ao esquecimento desde a modalidade de ação declaratória até uma ação indenizatória; o terceiro coaduna-se com as características passíveis de identificação com o direito ao esquecimento; por fim, o quarto ponto relaciona o conteúdo da decisão e o seu grau de interação com os meios digitais.

Salienta-se que o presente estudo tem por finalidade apresentar os principais reflexos da aplicação da teoria do direito ao esquecimento no contexto do TJ/SP. Nesta perspectiva, é cediço que o emprego dos marcadores "direito" e "esquecimento" limitam o número de decisões encontradas, uma vez que ao tema podem ser atribuídas outras expressões, porém, o uso de marcadores distintos ensejaria uma quantidade marcadamente superior de decisões, o que inviabilizaria a concretização deste estudo.

\subsection{TRIBUNAL DE JUSTIÇA DE SÃO PAULO: ANÁLISE DOS RESULTADOS}

A análise referente ao Tribunal de Justiça de São Paulo teve como objeto 40 acórdãos, dentre os quais 28 correspondem a apelações e 12 a agravos de instrumento.

A primeira apelação objeto de análise (919474716.2008.8.26.0000) refere-se ao pedido indenizatório formulado por um indivíduo em face de uma editora local, pela veiculação de matéria jornalística cuja finalidade era rememorar os principais assuntos veiculados nos últimos 30 anos no jornal. O TJ/SP negou provimento ao recurso sob o argumento de que a matéria não tinha a finalidade de expor sobremaneira o acusado, mas tão somente rememorar fatos passados. Assim, caberia apenas um pedido de explicação em uma edição do jornal local para elucidar as consequências do fato exposto.

A segunda apelação (0007766-17.2011.8.26.0650) teve como pretensão a exclusão de notícia do site da empresa Folha da Manhã. A

sentido do seu reconhecimento para negativação da folha de antecedentes criminais, pelo decurso do tempo. 
decisão pontuou os fatores interesse público e informação histórica, os quais, na visão dos julgadores, não foram evidenciados, motivo que ensejou o provimento do recurso, para a exclusão da notícia impugnada.

A decisão, referente à apelação ${ }^{\circ}$ 0141604-23.2012.8.26.0100, teve como recorrente o jornal O Estado de São Paulo, o qual recorreu da decisão que determinou a exclusão de matéria de seu site, alegando ser lícito o seu conteúdo. Sob o mesmo argumento acima exposto, o Desembargador negou provimento ao recurso, prestigiando a dignidade humana em detrimento do direito à informação.

A apelação de $n^{\circ}$ 1024229-13.2014.8.26.0100 teve a pretensão de suprimir do mecanismo de busca Google termos que relacionasse o autor à imagem da ex-mulher. O desembargador relator Claudio Godoy afirmou que há dados que são indissociáveis da posição ocupada pelo autor na comunidade, bem como, não vislumbrou nenhum elemento passível de comprometimento da reputação do recorrente, justificativa determinante para o não provimento do recurso.

Em relação ao pedido constante no recurso de apelação $n^{\circ}$ 1003642-61.2014.8.26.0005 o autor interpôs o pedido de desindexação de notícias em face do provedor de busca Google. O autor foi investigado por suposto abuso cometido na prisão de uma escrivã de polícia, sendo que o inquérito fora arquivado no ano seguinte. A decisão ponderou o direito à liberdade de expressão e à privacidade pela mesma perspectiva da ponderação realizada com a liberdade de imprensa. Ademais, considerou que a passagem do tempo é responsável pela irrelevância de um acontecimento tido por público, e por estes motivos o recurso do autor foi provido.

A decisão referente à apelação $n^{\circ}$ 9000007-78.2007.8.26.0037, teve como pedido a exclusão de reportagem do site da empresa Folha da Manhã e a indenização pelos danos morais suportados pelo autor. $\mathrm{O}$ entendimento firmado pelos desembargadores foi o de que há interesse público na veiculação da matéria e sua supressão integral ensejaria coibição à liberdade de expressão da ré. Entenderam que não houve violação aos direitos da personalidade e nem abuso no direito de informar.

O recurso foi parcialmente provido, trazendo inovação ao contexto da ponderação entre a liberdade de informar e o direito ao esquecimento, pela seguinte ótica: determinação à empresa ré para que promova a exclusão do nome do autor da matéria, ou acrescente hyperlink ou nota ao final da reportagem para explicar que o referido indivíduo não foi condenado pela prática de nenhum crime. 
A análise da apelação $n^{\circ}$ 1002904-21.2015.8.26.0011 evidenciou que o pedido se baseou na supressão de informações referente a processos judiciais que poderiam ser encontrados através da empresa ré Google. O resultado foi o não provimento do recurso, sob o argumento de que a autora se limitou a indicar lista de links que pretende ver excluídos, sem apresentar o conteúdo dos sites, o que inviabiliza o julgamento sobre a violação ou não de algum direito.

$\mathrm{Na}$ apelação $\mathrm{n}^{\circ}$ 1082816-28.2014.8.26.0100, cujo pedido era o da exclusão dos nomes dos autores da lista de empregadores que submeteram trabalhadores a condições análogas a de escravo, o recurso foi parcialmente provido para condenar a empresa Google a inibir as matérias indicadas pelos recorrentes.

Sob os mesmos argumentos, e com os mesmos pedidos, a empresa autora interpôs apelação em face de Yahoo do Brasil Internet Ltda. O voto do relator Rui Cascaldi foi no sentido de não dar provimento ao recurso a partir de duas teses: não possibilidade de reconhecimento do direito ao esquecimento a fatos ilícitos praticados recentemente e afastamento da responsabilização do provedor de busca, o qual apenas promove a indexação do conteúdo de sites já existentes.

No recurso de apelação n ${ }^{\circ}$ 0160205-48.2010.8.26.0100, o Google recorreu da decisão que determinou a remoção de marcadores relacionados ao nome artístico e vídeos da autora, sendo o recurso julgado procedente, pois, segundo o entendimento dos julgadores, verificou-se que a conduta atual da autora da demanda não é diferente daquela existente em seu passado, quando essa atuava como atriz pornográfica.

A apelação $n^{\circ}$ 0004144-77.2015.8.26.0297, na mesma esteira, teve como recorrente a empresa Google, sob a alegação de que não possui o domínio sobre as informações indicadas pela autora e que a retirada dos marcadores não resolveria o problema, vez que poderiam ser acessadas através de outros provedores de busca. Neste sentido, a decisão foi de não provimento do recurso, pois da ponderação entenderam os julgadores que deve, no caso em exame, prevalecer o direito fundamental à inviolabilidade da intimidade do condenado que já cumpriu a respectiva pena.

A apelação ${ }^{\circ}$ 0006475-29.2011.8.26.0020 indica decisão na qual o polo passivo refere-se a empresa jornalística, que aos moldes da primeira decisão analisada, produziu matéria retrospectiva sobre o Impeachment do ex-Presidente Fernando Collor de Mello. O autor pleiteou indenização, sendo esta negada pela tese de que se refere a acontecimento integrante da história recente do País e houve apenas a reprodução de conteúdo já 
veiculado em livro de ampla difusão, não caracterizando informações novas.

Na apelação $\mathrm{n}^{\circ}$ 1013774-86.2014.8.26.0100, referente ao pedido de retirada de resultados de pesquisa sobre notícias vinculadas ao réu, o recurso foi provido para a empresa Google e improvido para o autor. Entendeu-se que o Google apenas disponibiliza os conteúdos e que a imposição da obrigação a ele seria medida inócua, pois as informações continuariam a ser veiculadas através de outros sites de busca. Além disso, na ponderação entre os direitos tutelados, firmou-se que o direito ao esquecimento não pode se sobrepor ao direito de informação e publicidade dos processos judiciais.

A decisão acima exposta, entendeu que não se deve responsabilizar o Google, dada a existência de outros provedores que realizam a mesma atividade, e no que tange à ponderação, a tutela do esquecimento não pode se sobrepor ao direito à informação. Ainda, expôsse que o autor foi condenado na esfera criminal, o que não lhe garante a supressão destas informações por se relacionarem ao interesse público.

O acórdão referente à decisão contida na apelação $\mathrm{n}^{\circ} 1013949$ 46.2015.8.26.0003 apresenta o pedido de supressão de decisão judicial sobre reclamação trabalhista movida pelo autor em face da empresa em que trabalhava. Ante a justificativa de que se trata de mera referência jurisprudencial abrangida pelo princípio da publicidade dos atos judiciais, houve o não provimento do recurso.

A ação de obrigação de fazer, cujo pedido era o da retirada do vídeo da plataforma de pesquisa, cumulado com indenização por danos morais, em fase recursal, (apelação n ${ }^{\circ}$ 1075998-60.2014.8.26.0100), foi julgada parcialmente provida, apenas para que a empresa ré disponibilizasse os dados do usuário que incluiu o vídeo na rede de computadores.

Em caso semelhante ao analisado acerca da veiculação de informações sobre a participação em grupo de corrupção, a apelação $\mathrm{n}^{\circ}$ 1013430-56.2015.8.26.0008 não foi provida pelos argumentos seguintes: trata-se de informação jornalística que não apresentou nenhum conteúdo inverídico; com fundamento no art. 19 da Lei $\mathrm{n}^{\circ} 12.965$ retirou a possibilidade de responsabilização da empresa Google; e no sopesamento entre os direitos conflitantes, prevaleceu o interesse público de acesso à informação.

O acórdão contido na apelação n ${ }^{\circ}$ 0001127-59.2013.8.26.0020, refere-se ao pedido de exclusão de matéria jornalística do site o Estado de 
São Paulo e do pedido da empresa ré para que não tivesse que apagar o conteúdo. Diferente de entendimento já exposto anteriormente, o recurso não foi provido para o autor, que fora inocentado na esfera criminal dos delitos imputados a ele. Restou, assim, a determinação para que a empresa jornalística acrescente hyperlink no nome do autor ou nota no final da matéria para elucidar que não restou a comprovação de nenhum crime praticado por ele.

Esta decisão apresenta uma das modalidades de manifestação do direito ao esquecimento no TJ/SP, a de acréscimo de hyperlink com atualização da informação e não sua desindexação.

A apelação $\mathrm{n}^{\circ}$ 1010656-48.2014.8.26.0506, na qual recorreram ambas as partes, teve como solução eximir o provedor de busca Google pela veiculação da matéria de conteúdo supostamente ofensivo à honra do autor, pela perspectiva de que a informação poderia ser encontrada em outros sites de buscas.

A apelação $\mathrm{n}^{\mathrm{o}}$ 1014259-89.2014.8.26.0002 trouxe acordão cuja discussão envolve a retirada de informação do meio digital, que, segundo o autor, ofende sua carreira de médico, por se questionar a qualidade dos seus serviços. Salientaram os julgadores a falta do interesse público na manutenção do conteúdo, já que a matéria se encontra no portal há 3 anos. $\mathrm{E}$ da antinomia entre os princípios conflituosos, a dignidade da pessoa humana faz prevalecer o direito da personalidade do autor, conforme conclusão do acórdão.

A apelação seguinte (1000565-65.2016.8.26.0040), com pedido semelhante ao da anterior, acrescido de indenização por danos morais, teve o recurso não provido. O acordão fundamentou-se no juízo de proporcionalidade entre o interesse público e os direitos da personalidade, sendo que se entendeu pela garantia daquele.

$\mathrm{O}$ acórdão referente à apelação $\mathrm{n}^{\circ}$ 0067726-65.2012.8.26.0100 deu provimento ao recurso adesivo do autor da ação de indenização por dano moral, todavia, julgou pelo não provimento da apelação interposta pela ré. Trata-se de fato que envolveu a veiculação de matéria jornalística sobre a situação vivida pela apelante por emissora de televisão. Em juízo de ponderação, o relator entendeu que o limite ao direito de informar consiste na possibilidade de violação ao direito à intimidade, à vida privada, à honra e à imagem, direitos voltados à proteção da própria dignidade humana.

A apelação $\mathrm{n}^{\circ}$ 0005077-59.2013.8.26.0543 compreende recurso interposto em face da Empresa Folha da Manhã, pelo qual o autor/apelante 
sustentou a supressão de notícia na qual lhe foi imputada a prática de crime sexual no exercício da atividade sacerdotal. A empresa ré, dentre outros argumentos, sustentou a existência de prescrição. A alegação da ré foi afastada por entender os julgadores tratar-se de ato supostamente lesivo que se protrai no tempo, no entanto, não cabível a supressão da matéria por ensejar insegurança jurídica aos meios comunicativos e por se revelar contrária à existência de fatos ocorridos, compreendidos na história nacional.

O recurso de apelação $n^{\circ}$ 1126822-86.2015.8.26.0100 buscou a responsabilização da empresa Google pela necessidade de desindexação do nome dos autores aos resultados referentes à sentença criminal não transitada em julgado da qual são réus. $O$ recurso não foi provido sob o fundamento de que os provedores de busca não são obrigados a filtrar o conteúdo de seus resultados.

$\mathrm{O}$ autor/apelante recorreu da ação de obrigação de fazer contra a empresa Yahoo (apelação $n^{\circ} 1073052-18.2014 .8 .26 .0100$ ) para a exclusão de links específicos difamatórios e caluniosos. Na mesma esteira da decisão acima, refere-se à responsabilização de provedor de busca. Nesse caso o recurso foi provido, justificando a condenação da empresa ré no fato de que os direitos da personalidade configuram como bem maior ante o direito à informação.

A apelação $n^{\circ}$ 0001102-24.2015.8.26.0619, também referente ao pedido de desindexação de informações relacionadas ao nome do autor, foi movida pelo autor em face da empresa Google. O recurso provido teve como base o grau de relevância social da informação, o que ensejou a responsabilização do provedor de busca pela supressão dos links apresentados pelo autor.

$\mathrm{Na}$ apelação $\mathrm{n}^{\circ}$ 1005019-40.2017.8.26.0077, na qual o autor/apelante pleiteava posse em cargo público, sob o fundamento do direito ao esquecimento. $\mathrm{O}$ não provimento do recurso se deu pelo entendimento de que a exigência constante no edital da necessidade de conduta ilibada constituía um dos pressupostos para o exercício e não poderia ser acobertada pelo direito ao esquecimento.

$\mathrm{Na}$ apelação interposta (1074790-41.2014.8.26.0100), cuja demanda era a exclusão de matéria divulgada pela ré sobre suposta prática de pedofilia, o juízo recursal manifestou-se no sentido de que a inviolabilidade da intimidade da vida privada condiciona o direito à livre expressão, e no caso concreto, evidenciada a violação à intimidade, o 
recurso não foi provido, exigindo-se a manutenção da sentença que determinara a exclusão da matéria.

O último acórdão de apelação (1126160-88.2016.8.26.0100) expôs pedido de indisponibilidade de resultados de pesquisa por parte do Google, uma vez que respondeu a ação criminal já extinta. O recurso não foi provido sob dois argumentos: a empresa Google não deve ser responsabilizado por não possuir o domínio sobre as informações e a gravidade do delito praticado legitima a manutenção das informações, dada a utilidade para a coletividade.

No campo recursal do agravo de instrumento, o principal pedido foi o de exclusão da matéria, ou a desindexação do nome do autor da demanda da sua relação com notícias tidas por indesejadas, em sede de tutela de urgência, a qual, em conformidade com o art. 300 do Código de Processo Civil, deve ser concedida quando presentes os seguintes requisitos: elementos que evidenciem a probabilidade do direito, também conhecido pela doutrina como fumus boni iuris, e o perigo de dano ou o risco ao resultado útil do processo, invocado como periculum in mora.

Nota-se que das 40 decisões extraídas, 37 referem-se a problemas relacionados ao uso da internet, o que corresponde a $92,5 \%$ do total analisado quanto ao TJ/SP. Outro ponto pertinente é a instabilidade de responsabilização dos provedores, dada a paridade na quantidade de decisões opostas ${ }^{56}$ : 8 decisões atribuíram aos provedores de busca a responsabilidade pelas informações, ao passo que 7 decisões dispuseram sobre a responsabilidade dos provedores de hospedagem. Por outro lado, 11 foi o total de casos em que os provedores de busca tiveram a responsabilidade afastada.

Por fim, destaca-se que sendo o problema majoritariamente relacionado ao uso da internet, menos de $10 \%$ do total (3 decisões) utilizaram expressamente a Lei ${ }^{\circ} 12.965 / 14$ para fundamentar a conclusão a que chegaram os julgadores.

\section{CONSIDERAÇÕES FINAIS}

Como já exposto, os direitos, podem se conflitar, tendo em vista a amplitude de sua atuação, a ausência de leis infraconstitucionais que

\footnotetext{
${ }^{56} \mathrm{~A}$ análise quanto à responsabilização ou não dos provedores de busca e hospedagem foi realizada tendo como total o número de 28 decisões, já que nas demais não houve discussão sobre a responsabilidade dos provedores.
} 
estabeleçam balizas à afirmação desses direitos, bem como pelas mudanças perpetradas pelo avanço tecnológico nas relações sociais e jurídicas.

Assim, o avanço tecnológico, com a difusão do uso da Internet, como já evidenciado, ensejou alterações também no contexto jurídico, como a recente discussão sobre a possibilidade de reconhecimento do direito ao esquecimento.

Convém ressaltar que não há no ordenamento jurídico brasileiro previsão expressa acerca do direito ao esquecimento, todavia, há autores que entendem que esse direito possui previsão implícita no art. $7^{\circ}$ da Lei do Marco Civil da Internet. Ainda, não se pode olvidar do fato de que no Brasil não existe lei específica para a proteção dos dados pessoais.

Vê-se assim que o Judiciário tem sido provocado a se posicionar sobre tal situação, através dos inúmeros pedidos judiciais existentes, o que justificou o interesse pela análise das decisões proferidas em sede recursal pelos Tribunais brasileiros.

No âmbito do Tribunal de Justiça do Estado de São Paulo foi possível perceber a contrariedade existente quanto ao reconhecimento da necessidade da tutela do esquecimento em meio digital. É inegável o fato de se referir a tema atual e resultado do acesso aos meios digitais, já que das 40 decisões extraídas do sítio eletrônico, 37 relacionavam-se com a existência de informações digitais.

No entanto, embora referiam-se à relação da notícia com meios digitais, em menos de $8 \%$ das decisões proferidas pelo TJ/SP foi citada a Lei $n^{\circ} 12.965 / 14$, ou seja, é possível perceber o distanciamento entre o texto legal e sua efetivação.

$\mathrm{O}$ direito ao esquecimento tem se manifestado de formas variadas, já que pode ser percebido através de quatro modos: i) o apagamento do conteúdo tido por indesejado diretamente do site de notícias, ou seja, do provedor de hospedagem; ii) supressão do conteúdo de uma determinada matéria dos provedores de busca; iii) desindexação do nome de um indivíduo da sua relação com determinadas notícias; e iv) atualização do conteúdo informativo. O terceiro modo distingue-se do segundo, já que naquele a matéria continua a ser veiculada por meio dos provedores de busca e pode ser encontrada por meio de outros marcadores que não o nome da pessoa que pleiteou a desindexação, enquanto que no segundo modo, a notícia como um todo é suprimida do motor de busca. Quanto à atualização do conteúdo, a matéria apenas recebe a inclusão de um hyperlink ou nota de rodapé explicando a atual situação jurídica dos envolvidos no fato. 
Em síntese, o estudo em questão evidenciou a carência de embasamento das decisões seja pelo deferimento ou pelo indeferimento do direito ao esquecimento. $\mathrm{O}$ aspecto substancial encontrado foi o de que, embora a técnica da ponderação se apresente como a mais utilizada e atual, esta garante significativa insegurança jurídica, dada a existência de decisões substancialmente contrárias para casos idênticos, bem como a ausência de conexão do tema com a Lei n ${ }^{\circ} 12.965 / 2014$.

\section{REFERÊNCIAS BIBLIOGRÁFICAS}

ALEXY, Robert. Teoria dos Direitos Fundamentais. 2. ed. São Paulo: Malheiros, 2015.

ARAUJO, Luiz Alberto David; NUNES JÚNIOR, Vidal Serrano. Curso de Direito Constitucional. 14. ed. São Paulo: Saraiva, 2010.

BARROSO, Luis Roberto. Colisão entre liberdade de expressão e direitos da personalidade. Critérios de ponderação. Interpretação constitucionalmente adequada do código civil e da lei de imprensa. Revista de Direito Administrativo, Rio de Janeiro, v. 235, p.1-36, mar. 2004.

. Curso de Direito Constitucional contemporâneo: Os conceitos fundamentais e a construção do novo modelo. São Paulo: Saraiva, 2009.

BRASIL. Constituição (1988). Constituição da República Federativa do Brasil. Brasília, DF: Senado, 1988.

. Lei $\mathrm{n}^{\circ} 12.965$, de 23 de abril de 2014. Estabelece princípios, garantias, direitos e

deveres para o uso da Internet no Brasil. Diário Oficial [da] República Federativa do Brasil, Brasília, DF, 24 abr. 2014. Disponível em: < http://www.planalto.gov.br/ccivil_03/_ato2011 -

2014/2014/lei/112965.htm>. Acesso em 05 ago. 2018.

. Tribunal de Justiça do Estado de São Paulo. Agravo de instrumento no 2133542 -

95.2014.8.26.0000. Agravante: F. H. Agravada: Yahoo do Brasil Internet Ltda. São Paulo, 9 out. 2014.

. Tribunal de Justiça do Estado de São Paulo. Agravo de instrumento n ${ }^{\circ} 2186767-$

30.2014.8.26.0000. Agravante: W. P. e A. L. L. P. Agravada: Google Brasil Internet LTDA., Yahoo do Brasil Internet Ltda. e Microsoft Informatica LTDA. São Paulo, 11 nov. 2014.

. Tribunal de Justiça do Estado de São Paulo. Agravo de instrumento nº 2011446 -

44.2015.8.26.0000. Agravante: Folha da Manhã S/A. Agravada: E. G. S. São Paulo, 20 mar. 2015.

. Tribunal de Justiça do Estado de São Paulo. Agravo de instrumento no 2031385 -

10.2015.8.26.0000. Agravante: Google Brasil Internet LTDA. Agravada: E. H. C. F. São Paulo, 26 mar. 2015. 
. Tribunal de Justiça do Estado de São Paulo. Agravo de instrumento ${ }^{\circ} 2228043$ 41.2014.8.26.0000. Agravante: Google Brasil Internet LTDA. Agravada: A. A. S. São Paulo, 14 mai. 2015.

. Tribunal de Justiça do Estado de São Paulo. Agravo de instrumento no 2231221 95.2014.8.26.0000. Agravante: Yahoo do Brasil Internet LTDA. Agravada: A. A. S. São Paulo, 14 mai. 2015.

. Tribunal de Justiça do Estado de São Paulo. Agravo de instrumento n $2108414-$ 39.2015.8.26.0000. Agravante: D. V. Q. Agravada: Google Brasil Internet LTDA. São Paulo, 29 jun. 2015.

. Tribunal de Justiça do Estado de São Paulo. Agravo de instrumento n ${ }^{\circ} 2231131$ 87.2014.8.26.0000. Agravante: Microsoft Informática Ltda. Agravada: A. A. S. São Paulo, 8 jul. 2015.

Tribunal de Justiça do Estado de São Paulo. Agravo de instrumento no 221587167.2014.8.26.0000. Agravante: R. K. F. Agravada: Google Brasil Internet LTDA. São Paulo, 28 jul. 2015.

Tribunal de Justiça do Estado de São Paulo. Agravo de instrumento n ${ }^{\circ} 205316$ 20.2016.8.26.0000. Agravante: M. G. S. Agravada: Goshme Soluções para Internet Ltda. Me. São Paulo, 8 nov. 2016.

Tribunal de Justiça do Estado de São Paulo. Agravo de instrumento ${ }^{\circ} 2182564$ 54.2016.8.26.0000. Agravante: C. B. Agravada: Google Brasil Internet LTDA. São Paulo, 12 jan. 2017.

. Tribunal de Justiça do Estado de São Paulo. Agravo de instrumento n ${ }^{\circ} 2171573$ 82.2017.8.26.0000. Agravante: L. A. P. Agravada: Google Brasil Internet LTDA. São Paulo, 16 out. 2017.

Tribunal de Justiça do Estado de São Paulo. Apelação cível no $9194747-$

16.2008.8.26.0000. Apelante: S. S. A. Apelada: Editora Itatiba LTDA. São Paulo, 14 nov. 2013.

Tribunal de Justiça do Estado de São Paulo. Apelação cível nº 0007766-

17.2011.8.26.0650. Apelante: C. A. L. Apelada: Empresa Folha da Manhã. São Paulo, 8 mai. 2014.

Tribunal de Justiça do Estado de São Paulo. Apelação cível no 0141604-

23.2012.8.26.0100. Apelante: S. A. O Estado de São Paulo. Apelada: J. M. M. P. São Paulo, 13 nov. 2014.

Tribunal de Justiça do Estado de São Paulo. Apelação cível no $1024229-$

13.2014.8.26.0100. Apelante: R. S. L. Apelada: Google Brasil Internet LTDA. São Paulo, 25 nov. 2014.

Tribunal de Justiça do Estado de São Paulo. Apelação cível nº 1003642-

61.2014.8.26.0005. Apelante: E. H. C. F. Apelada: Google Brasil Internet LTDA. São Paulo, 2 dez. 2014. 
Tribunal de Justiça do Estado de São Paulo. Apelação cível no 9000007 -

78.2007.8.26.0037. Apelante: L. R. F. Apelada: Empresa Folha da Manhã S/A. São Paulo, 24 fev. 2015.

Tribunal de Justiça do Estado de São Paulo. Apelação cível no 1002904-

21.2015.8.26.0011. Apelante: S. G. M. Apelada: Google Brasil Internet LTDA. São Paulo, 23 fev. 2016.

Tribunal de Justiça do Estado de São Paulo. Apelação cível nº 1082816-

28.2014.8.26.0100. Apelante: M. S/A I. C.; W. D.; W. E. D.; A. C. D. e L. Z. D. Apelada: Google Brasil Internet LTDA. São Paulo, 1 mar. 2016.

. Tribunal de Justiça do Estado de São Paulo. Apelação cível no 0160205 -

48.2010.8.26.0100. Apelante: Google Brasil Internet LTDA. Apelada: M. H. J. M. São Paulo, 5 abr. 2016.

Tribunal de Justiça do Estado de São Paulo. Apelação cível no 0004144-

77.2015.8.26.0297. Apelante: Google Brasil Internet LTDA. Apelada: D. V. Q. São Paulo, 25 abr. 2016.

Tribunal de Justiça do Estado de São Paulo. Apelação cível nº 0006475-

29.2011.8.26.0020. Apelante: F. A. C. M. Apelada: Editora Abril S.A. São Paulo, 7 jun. 2016.

. Tribunal de Justiça do Estado de São Paulo. Apelação cível nº 1013774-

86.2014.8.26.0100. Apelante: Google Brasil Internet LTDA - Google SP e R. G. C. Apelada: R. G. C. e Google Brasil Internet LTDA - Google SP. São Paulo, 29 jun. 2016.

. Tribunal de Justiça do Estado de São Paulo. Apelação cível n 1013949-

46.2015.8.26.0003. Apelante: W. A. M. F. Apelada: Goshme Soluções para Internet Ltda. - ME e Google Brasil Internet. São Paulo, 22 nov. 2016.

. Tribunal de Justiça do Estado de São Paulo. Apelação cível nº 1075998-

60.2014.8.26.0100. Apelante: C. N. E. P. Ltda. ME. Apelada: Google Brasil Internet. São Paulo, 23 nov. 2016.

. Tribunal de Justiça do Estado de São Paulo. Apelação cível nº 1013430-

56.2015.8.26.0008. Apelante: G. T. Ltda. ME. Apelada: Google Brasil Internet Ltda. (e outras). São Paulo, 1 dez. 2016.

. Tribunal de Justiça do Estado de São Paulo. Apelação cível no 0001127-

59.2013.8.26.0020. Apelante: L. R. F e S/A o Estado de São Paulo. Apelada: S/A o Estado de São Paulo e L. R. F. São Paulo, 13 jun. 2017.

. Tribunal de Justiça do Estado de São Paulo. Apelação cível nº 1010656-

48.2014.8.26.0506. Apelante: Google Brasil Internet Ltda. e outro. Apelada: N. R. A. e outro. São Paulo, 21 jun. 2017.

. Tribunal de Justiça do Estado de São Paulo. Apelação cível no 1014259-

89.2014.8.26.0002. Apelante: Infoglobo Comunicação e Participações S.A. Apelada: A. G. C. São Paulo, 22 jun. 2017. 
Tribunal de Justiça do Estado de São Paulo. Apelação cível no $1000565-$

65.2016.8.26.0040. Apelante: L. J. S. Apelada: Gemece Empresa Jornalística LTDA ME. São Paulo, 27 jun. 2017.

. Tribunal de Justiça do Estado de São Paulo. Apelação cível nº 0067726-

65.2012.8.26.0100. Apelante: TV Record Rede Record de Televisão. Apelada: E. M. A. V. R.; M. V. R. e A. A. V. R. São Paulo, 30 ago. 2017.

. Tribunal de Justiça do Estado de São Paulo. Apelação cível no 0005077-

59.2013.8.26.0543. Apelante: J. V. M. Apelada: Empresa Folha da Manhã S A. São Paulo, 29 set. 2017.

Tribunal de Justiça do Estado de São Paulo. Apelação cível nº 1126822-

86.2015.8.26.0100. Apelante: A. S. C e outra. Apelada: Google Brasil Internet LTDA. São Paulo, 28 set. 2017.

. Tribunal de Justiça do Estado de São Paulo. Apelação cível nº 1073052-

18.2014.8.26.0100. Apelante: R. A. P. Apelada: Yahoo Internet do Brasil Ltda. São Paulo, 07 mar. 2017.

Tribunal de Justiça do Estado de São Paulo. Apelação cível no 0001102-

24.2015.8.26.0619. Apelante: J. A. S. Apelada: Google Brasil Internet Ltda. São Paulo, 18 out. 2017.

. Tribunal de Justiça do Estado de São Paulo. Apelação cível nº 1082874-

31.2014.8.26.0100. Apelante: M. S/A. Apelada: Yahoo do Brasil Internet Ltda. São Paulo, 31 out. 2017.

. Tribunal de Justiça do Estado de São Paulo. Apelação cível nº 1005019-

40.2017.8.26.0077. Apelante: C. A. D. Apelada: Prefeitura Municipal de Birigui. São Paulo, 13 nov. 2017.

Tribunal de Justiça do Estado de São Paulo. Apelação cível no 1074790-

41.2014.8.26.0100. Apelante: D. S. J. / Destak Brasil Editora S/A. Apelada: Destak Brasil Editora S/A / D. S. J. São Paulo, 5 dez. 2017.

Tribunal de Justiça do Estado de São Paulo. Apelação cível nº 1126160-

88.2016.8.26.0100. Apelante: E. L. A. Apelada: Google Brasil Internet Ldta. São Paulo, 14 dez. 2017.

BULOS, Uadi Lammêgo. Curso de Direito Constitucional. 8. ed. São Paulo: Saraiva, 2014.

CANOTILHO, José Joaquim Gomes. Direito Constitucional. 6. ed. Coimbra: Almedina, 1993.

COURT OF APPEAL OF CALIFORNIA. MELVIN v. REID: documento eletrônico. California: 1931. Disponível em: <https://casetext.com/case/melvin-v-reid>. Acesso em 05 ago. 2018.

FARIAS, Edilsom Pereira de. Colisão de direitos: A honra, a intimidade, a vida privada e a imagem versus a liberdade de expressão e informação. Porto Alegre: Sergio Antonio Fabris Editor, 1996. 
FREITAS FILHO, Roberto; LIMA, Thalita Moraes. Metodologia de Análise de Decisões. Universitas Jus, Brasília, v. 21, n. 1, p.1-17, dez. 2010.

GOMES, Orlando. Introdução ao Direito Civil. 5. ed. Rio de Janeiro: Forense, 1977.

LIMA, Cíntia Rosa Pereira de. Direito ao esquecimento e internet: o fundamento legal no direito comunitário europeu, no direito italiano e no direito brasileiro. Revista dos Tribunais Online, São Paulo, v. 8, p.511-543, ago. 2015.

MARTINS NETO, João dos Passos; PINHEIRO, Denise. Liberdade de informar e direito à memória - uma crítica à ideia do direito ao esquecimento. Revista Novos Estudos Jurídicos, Itajaí, v. 19, n. 3, p.808-838, dez. 2014.

MAZZUOLI, Valerio de Oliveira. Direitos comunicativos como direitos humanos: abrangência, limites, acesso à Internet e direito ao esquecimento. Revista do Direito de Língua Portuguesa, Lisboa, v. 6, n. 1, p.219-240, dez. 2015.

MURATA, Daniel Peixoto. Proporcionalidade - insuficiências morais e teóricas. Teoria Jurídica Contemporânea, Rio de Janeiro, v. 2, n. 1, p.36-62, dez. 2016.

QUESADA, Francisco Mesa. Dimensión constitucional del derecho al olvido. Derecho y Cambio Social, Lima, v. 49, p.1-31, set. 2017.

RUARO, Regina Linden; MACHADO, Fernando Inglez de Souza. Ensaio a propósito do direito ao esquecimento: limites, origem e pertinência no ordenamento jurídico brasileiro. Revista de Direito Público, Londrina, v. 17, n. 1, p.204-233, maio 2017.

SARLET, Ingo Wolfgang. Dignidade da pessoa humana e direitos fundamentais na Constituição de 1988. 4. ed. Porto Alegre: Livraria do Advogado, 2006.

SCHREIBER, Anderson. Direitos da personalidade. 2. ed. São Paulo: Atlas, 2013.

SILVA, José Afonso da. Curso de Direito Constitucional Positivo. 36. ed. São Paulo: Malheiros, 2013.

STRECK, Lenio Luiz. O que é isto - decido conforme minha consciência? 4. ed. Porto Alegre: Livraria do Advogado, 2013.

TAVARES, André Ramos. Liberdade de expressão-comunicação, limitações quanto ao seu exercício e possibilidade de regulamentação. In: CAMARGO, Marcelo Novelino (Org.). Leituras complementares de direito constitucional: Direitos Fundamentais. 2. ed. Salvador: Juspodivm, 2007. p. 229-243. 